\title{
Uma longa noite de angústia
}

\section{Ana Cecília Acioli Lima}

Doutora em Teoria da Literatura pelo Programa

de Pós-graduação em Letras da Universidade

Federal de Pernambuco, professora da Faculdade

de Letras da Universidade Federal de Alagoas,

Coordenadora da Casa de Cultura Britânica

(Fale/Ufal) e Vice-coordenadora do GT A Mulher

na Literatura (ANPOLL) no biênio 2008-2010. 

Meu olhar angustiado penetrava a fria estrutura plástica, que, ainda assim, permanecia muda. Pouco a pouco, ficava menos nítida; já não distinguia os números nas teclas. O que meus olhos já não alcançavam, meus ouvidos ansiavam por escutar: um toque, apenas. Não deixaria vir um segundo.

Dei-me conta, em um suspiro, que havia suspendido o tempo. O próximo instante, em que o telefone irá tocar, é agora sempre. E, assim, congelada eu, congelado o tempo, esperava o mesmo momento, insuportavelmente adiado.

Há uns dias lhe encontrei na seção de cds da minha livraria preferida. Claro que você não havia esquecido. Fazia um bom tempo que não nos víamos, depois que você tinha voltado da Inglaterra. Ou não? Complicado lidar com o tempo. Não calculava o intervalo que estávamos distantes, fisicamente. Continuava vivendo do seu lado. Era assim que eu via as nossas vidas, irremediavelmente entrelaçadas. Dessa certeza não me desfazia.

E lá estava você, de fato, do meu lado. No entanto, não mais real. Uma sensação de estranhamento me tomou assim de súbito. Quanto mais sentia a sua presença, mais fugia de mim a sua imagem. Você falava da nossa história, na qual não me reconhecia. Não era a "minha" nossa história. Como pode ser? Meu rosto se transformou numa interrogação.

Cá estou eu, no escuro, tentando recuperar os fatos; tentando aproximar as nossas memórias, enquanto o que mais existe de concreto é o telefone que não lhe traz.

Queria poder perfurar o tempo, descer no seu espiral, e investigar cada recanto que, hoje, não consigo alcançar.

Você me falava das suas viagens, dos cursos que fez, das pessoas interessantes que conheceu, dos livros que leu... Eu tentava capturar a sua presença e encaixá-la na minha história.

_ “Ah! Você conhece essa cantora? Tá fazendo muito sucesso na Europa!" 
- "Não... nunca ouvi falar. É mesmo?"

Você segurava a minha mão com entusiasmo. A cada toque, no entanto, você desvanecia. Eu fixava minha mente e meu olhar, mas você não existia.

A voz. Ondas de som transmitidas por meio de corrente elétrica, a voz no telefone seria mais real! Impalpável, mas feita sólida no aparelho. A tecnologia é real. Será? Meu Deus! Onde estava você?

Você conversava animadamente. Queria continuar a conversa em um jantar. Que ótimo, pensei, vamos ter mais tempo pra cruzar nossas lembranças, avaliações, impressões.

— "Eu te ligo amanhã!"

— "Tá certo. Vou esperar!"

- "Pode deixar! Temos que conversar com mais calma. Ligo sem falta!"

E assim nos despedimos, entre promessas caladas e esperanças reacendidas.

Hoje, estou aqui, esperando você ligar, desde ontem... Ou será desde a semana passada? Bom, todo dia é hoje, não é? E sempre será amanhã. Você ficou de me ligar amanhã.

Sem falta! 